affairs/news/2017/06/address_by_ministerfreelandoncanadasforeignpolicypriorities.html [Accessed $20^{\text {th }}$ November 2017].

17. CONNOLLY, A. (2017) Canada must stand up as American leadership withers: Freeland. Ipolitics.ca. - [Online] Available from: http://ipolitics.ca/2017/06/06/canada-must-stand-up-as-americanleadership-withers-freeland [Accessed: $17^{\text {th }}$ November 2017].

18. MACLEAN'S (2017) Chrystia Freeland on Canada's foreign policy: Full speech. As the U.S. turns inward, Canada's foreign minister pledges openness - and Canadian leadership - on the international stage. [Online] 6 June. - Available from: http://www.macleans.ca/politics/ottawa/chrystiafreeland-on-canadas-foreign-policy-full-speech [Accessed: 19 ${ }^{\text {th }}$ November 2017].

Надійшла до редколегії02.09.2017

Maryna Bessonova, PhD (history), Senior Research Fellow the State Institution "The Institute of World History of the National Academy of Sciences of Ukraine”

\title{
COMMON CHALLENGES AND THREATS TO THE NATIONAL INTERESTS OF THE UNITED STATES AND CANADA (late 20th - early 21st century)
}

\begin{abstract}
The article attempts to outline the main challenges and threats to the national interests in the late XXth - early XXIst century on the example of the USA and Canada. A review of the period from the end of the Cold War to the present day in two major dimensions, axiological and geographic, has been carried out. The former is focused on identifying the basic and essential features of those threats and challenges which are distinguished for the American and Canadian foreign policies. This dimension has been analyzed within the context of core values to which American and Canadian politicians appeal on both domestic and international arenas. The latter outlines those major regions detached as menacing the United States and Canada.

Both leading democratic states combine "national" and "international" values in substantiating of their foreign policy. The basic democratic and universal human values are subject to special attention. It is generalized that the main modern dangers for both countries represent mostly axiological, not geographic dimension. That is why among the main threats to the American and Canadian national interests one can distinguish those as follows: terrorism, climate change, proliferation of nuclear and other weapons of mass destruction, challenges to the cyber-security, uncontrolled migration, international crime, failed states etc. It is concluded that the universal nature of the values, the protection of which is the basis of the current foreign policy of both states, is coherent to the universal nature of the dangers that arise for the American and Canadian national interests.
\end{abstract}

Key words: USA, Canada, foreign policy, threats, challenges, national interests.

УДК: 94: 329.733 (477+73+71)«1960/1993»

http://doi.org/10.17721/2521-1706.2018.04.216-227

Володимир Бондаренко, доктор історичних наук, доцент, Запорізький національний університет

\section{УКРАЇНСЬКИЙ ВІЛЬНОКОЗАЦЬКИЙ РУХ У США І КАНАДІ У 1960 - 1993 PР.}

\begin{abstract}
Анотація. У статті розглядається актуальна проблема використання військовополітичного досвіду української діаспори у сучасному військовому будівнищтві України. Досліджусться український вільнокозащький рух у 1960 - 1993 рр. у США $i$ Канаді. Аналізуються особливості украӥнського вільнокозацького руху у $60-80-x$ pp. XX cm. Визначаються основні напрями діяльності організацій Вільного козаџтва у США і Канаді.
\end{abstract}


3'ясовуються причини занепаду руху у середині 80-х рp. ХХ ст. Узагальнено досвід Украӥнського Вільного козачтва у США $і$ Канаді для подальшого використання у діяльності державних органів України. Джерельною базою статті є опубліковані архівні документи, документи особистого походження, зарубіжна та украйнська преса того часу.

Дослідивши аспект проблеми, який став темою статті, автор дійшов до наступних висновків. Після завершення Другої світової війни український вільнокозачький рух продовжував діяти головним чином, серед украӥнської діаспори за межами СРСР $i$ сочіалістичних краӥн. Українське Вільне козацтво було типовою парамілітарною громадською організацією. Новим иентром Украӥнського Вільного козацтвва на початку 1960-х рр. стала Північна Америка. Напрямами діяльності упродовж післявоєнних років були: збереження національної ідентичності та козачьких традицій; військовопатріотичне виховання представників украӥнської діаспори, агітаційнопропагандистська діяльність із метою антикомуністичної боротьби, розробка воєнної доктрини та місия козацтва в майбутніх Збройних силах України, підготовка ідеології козацького руху та накопичення досвіду діяльності в умовах громадянського суспільства $i$ демократичного ладу.

Ключові слюва: українська діаспора, військова еміграція, український вільнокозацький рух, іррегулярні збройні формування, військове будівництво.

Українська діаспора як феномен сучасної історії привертає увагу дослідників не тільки як історичне явище, але й з точки зору практичного значення ії досвіду для сучасного українського державотворення. Частиною “другої” та “третьої хвилі” української еміграції були учасники збройних формувань, які боролися за незалежність України. Перебуваючи за межами України вони не тільки зберігали військові традиції та звичаї, займалися військово-патріотичним вихованням серед еміграції, а й вивчали досвід військового будівництва зарубіжних країн. Військові емігранти служили у багатьох арміях і брали участь у локальних війнах i конфліктах другої половини XX ст. - на початку XXI ст. Це стосується і українців громадян США i Канади. Після початку російсько-української війни багато українців у складі місії з допомоги Збройним силам України та в індивідуальному порядку допомагали у боротьбі з російською агресією. Досвід набутий у військовій сфері українською діаспорою на наш погляд потрібно вивчати та застосовувати у військовому будівництві України. Події 2014 - 2017 рр. довели важливе значення парамілітарних громадських об'єднань та іррегулярних збройних формувань. Згадаємо тільки про добровольчі формування, які стали першими на захист української державності та використання російським керівництвом донських i кубанських козацьких формувань у Криму та на Донбасі. Український вільнокозацький рух який діяв на еміграції з 1920 по 1993 рр. набув значний досвід у військово-політичній діяльності. Його козаки і старшини набули значний досвід участі в локальних війнах і конфліктах та військово-патріотичної роботи серед молоді і військовослужбовців у тому числі у США і Канаді. Тому на наш погляд $\epsilon$ доцільним дослідити і узагальнити досвід діяльності Українського вільнокозацького руху у США і Канаді у найбільш близькому до сучасних подій хронологічному періоді 1960- 1993 рр.

Після закінчення війни значна група громадян СРСР та емігрантів опинилася на теренах Німеччини і Австрії. Емігранти, які не були примусово репатрійовані, становили нову хвилю української еміграції. Учасники вільнокозацького руху в складі цієї хвилі відродили Українське Вільне козацтво (УВК) після війни на теренах Америки, Європи і Австралії. Проблема репатріації діяльності таборів 
інтернованих, переселення в нові країни перебування, громадсько-політична діяльність нової хвилі еміграції стали предметом вивчення дослідниками. Зазначимо, що гостра заполітизованість теми й відсутність доступу до архівних джерел не сприяли вивченню ii радянськими істориками до кінця 1980-х рр. Усе ж таки, окремі радянські історики вивчали репатріацію радянських громадян після війни та виникнення нової еміграції. Робилися спроби спростувати дослідження західних істориків, прикладом $\epsilon$ стаття, присвячена дослідженню Миколи Толстого, у якій повторювалися пропагандистські твердження про добровільність репатріації, відсутність репресій щодо репатріантів, перешкоди західних союзників [1]. Незважаючи на заангажованість, увагу дослідників привертає монографія М. Павленка, у якій не тільки розглядається політика СРСР і союзних держав щодо репатріації, але й дається характеристика нової хвилі української еміграції [2]. У 1950 - 1980-х рр. історію нової хвилі української еміграції почали досліджувати історики-емігранти. Безпосередні учасники подій намагалися оцінити чисельність, соціальний склад, країни поселення й особливості цієї хвилі української еміграції [3; 4]. У брошурі Олега Геруса, характеризуються хвилі української еміграції до Канади: чисельність, особливості, розміщення, вплив на громадсько-політичне життя українців Канади [5].

У 1990-х рр. українські дослідники вивчали “третю хвилю” української еміграції на основі нових архівних джерел. Спеціальні дослідження 3 проблеми репатріації українських біженців і переміщених осіб, їхнього проживання в таборах, переселення у країни Америки і Австралії з'явилися тільки на зламі XX XXI ст. Людмила Стрільчук у дисертації і статтях визначила чисельність, склад, особливості нової хвилі української еміграції та діяльність міжнародних організацій щодо роботи з ними [6 - 8]. Політику західних країн щодо переселення українських емігрантів до США і Канади розглянув в дисертації Сергій Рудик [9]. Юрій Недужко вивчив діяльність ДЦ УНР в екзилі після Другої світової війни та боротьбу української діаспори за незалежність України у 1950 - 1980-х рр. [10 12]. На наш погляд, “третя хвиля" української еміграції потребує подальшого ретельного вивчення українськими істориками, особливо після завершення переселення з таборів переміщених осіб. Фактично недослідженими залишаються аспекти проблеми, що стосуються української військової еміграції в 1945 - 1991 рр. Відзначимо, що український вільнокозацький рух також не був досліджений істориками.

Метою статті є дослідити український вільнокозацький рух у 1960 - 1993 pp. у США і Канаді. Згідно з метою визначені наступні завдання статті. Проаналізувати особливості українського вільнокозацького руху у $60-80$-х рр. ХХ ст. Визначити основні напрями діяльності організацій Вільного козацтва у США і Канаді. Дослідити причини занепаду руху у середині 80-х рр. ХХ ст. Узагальнити досвід українського Вільного козацтва у США і Канаді для подальшого використання у діяльності державних органів України. Джерельною базою статті є опубліковані архівні документи, документи особистого походження, зарубіжна та українська преса того часу.

Для кращого розуміння особливостей вільнокозацького руху після Другої світової війни необхідно коротко зупинитися на характеристиках української післявоєнної еміграції та порівняти іiї 3 еміграцією міжвоєнного періоду. Причинами “третьої хвилі” української еміграції стали, 3 одного боку, події довоєнного часу. У міжвоєнний період громадяни СРСР пережили голодомори, 
колективізацію, масові політичні репресії, релігійні утиски. Все це викликало негативну реакцію українського населення, а особливо в нещодавно приєднаних територіях Західної України. Тому частина населення намагалася уникнути повтору таких явищ і мала стійкі антикомуністичні настрої. Під час Другої світової війни нацистська окупаційна політика перемістила примусово значні маси українського населення до Німеччини. Це були військовополонені, остарбайтери, біженці та евакуйовані німецькою владою. Під впливом військових подій збройні колабораціоністські формування відступили разом 3 німецькими військами й опинилися на територіях Німеччини та Австрії. Міжвоєнні українські емігранти, намагаючись уникнути репресій з боку радянських органів державної безпеки i комуністичних режимів Східної Європи, відступили разом із гітлерівцями до Німеччини. Всі ці групи мали значну кількість людей, які не бажали повертатися на батьківщину, небезпідставно побоюючись репресій. Третя група причин виникла після закінчення війни, коли стало відомо про новий голод 1946 - 1947 рр., масові репресії, релігійні та національні утиски. Учасники ОУН і УПА після поразки в боротьбі змушені були емігрувати, щоб уникнути репресій. Таким чином, комплекс причин викликав нову хвилю української еміграції. На відміну від міжвоєнного періоду вона носила виключно політичний характер і була примусовою. Так само, як і у 1920 - 1930-х рр., вона була національно-політичною.

За типологією “третя хвиля" еміграції була головним чином компактномасовою, причому її особливістю було те, що вона “стартувала” не з самої України, а 3 території західних окупаційних зон Австрії та Німеччини, а також Італії. Чисельність індивідуальної еміграції була незначною. Пізніше, після переселення емігрантів, центрами “третьої хвилі” української еміграції стали США, Канада, країни Південної Америки та Австралія. До них i перемістилися центри вільнокозацького руху в 1960 - 1980-х рр.

Частиною “третьої хвилі” української еміграції була військова еміграція. УВК, як і в міжвоєнний період, було частиною військової еміграції. Тому зосередимо увагу на характеристиці післявоєнної військової еміграції. Вона складалася 3 декількох груп: колишні вояки Армії УНР, колишні командири та бійці Червоної армії 3 військовополонених, вояки колабораціоністських збройних формувань, вояки УПА. Необхідно звернути увагу, що ці групи часто перемішувалися, бо багато колишніх вояків Армії УНР служили в колабораціоністських формуваннях або в УПА. Колишні червоноармійці й командири також воювали в УПА та збройних колабораціоністських формуваннях. Все ж таки, найбільшу групу становили ті, хто воював в колабораціоністських формуваннях. Це відрізняло післявоєнну еміграцію від міжвоєнної. Більшість нової хвилі еміграції становили на відміну від попередньої, представники західноукраїнських земель. Це ще більше стосується військової еміграції. Значну частину колабораціоністських формувань становили військовополонені, які були представниками Наддніпрянської України, а тому підпадали під примусову репатріацію. Наочним прикладом цього може бути так звана 2-а дивізія Української національної армії, яка за різними оцінками від 30 до 50\% складалася з наддніпрянців. Фактично більшу ії частину було примусово репатрійовано до СРСР. Те ж саме взагалі необхідно віднести і до 75 тис. інших колабораціоністських формувань, які наприкінці війни формально ввійшли до Української національної армії (УНА). Визначення чисельності української військової еміграції після Другої світової війни ускладнюється тим, що учасники колабораціоністських формувань побоювалися примусової репатріації, а тому 
намагалися сховатися серед цивільних осіб. Багато хто змінював прізвище й навіть місце народження, бо західні українці не підпадали під визначення радянських громадян і переважно не видавалися на вимоги представників СРСР. Наочним прикладом цього є 1-а дивізія УНА, у якій наддніпрянці становили за різними даними від 20 до 30\%, але приховали своє походження і в більшості не були видані. Багато хто приховував участь у військових формуваннях на боці нацистської Німеччини, тому що йому могли відмовити у праві переселитися до США та Канади. Все ж таки, чисельність військової еміграції ніяк не була меншою, як у міжвоєнний період. Взагалі ця проблема потребує подальшого детального дослідження. Серед тих, хто опинився на еміграції, були й вояки козацьких колабораціоністських формувань, і це сприяло розгортанню вільнокозацького руху після війни. Крім того, серед українських вояків завжди пропагувалася козацька ідея та козацькі військові традиції. Тому багато представників військової еміграції прихильно ставилися до УВК і брали у ньому участь.

На наш погляд, цікавою $є$ доповідь американського дипломата Ландрефа Гаррісона “Український народ, як фактор боротьби проти радянського режиму”, яку було підготовлено влітку 1952 р. у Парижу для американського уряду. Вона на наш погляд, характеризувала українську еміграцію 3 точки зору тодішнього американського істеблішменту. Один із розділів автор присвятив стану української еміграції та іï можливостям і завданням у боротьбі з комунізмом. Американський дипломат вважав, що еміграція ввібрала в себе історичні проблеми та заплутаність у міжнародному положенні України минулих часів. 3 одного боку, довоєнний поділ України та еміграція формально різних країн - Польщі, Румунії, Чехословаччини, СРСР - надавала проблемі української еміграції міжнародного характеру. 3 іншого боку, емігранти виступали як $з$ антикомуністичних і антиросійських позицій, так i проти поляків. Значною проблемою, на думку американця, були розбіжності між західними та східними українцями у трактуваннях сутності комуністичного режиму, головних ворогів, мети боротьби. Серед недоліків української еміграції Л. Гаррісон зазначав міжусобну боротьбу, непослідовність у тактиці, відсутність чітких програм та ідеологічних установ, конфлікти з російською еміграцією й поляками. Він, головним чином, зосереджувався на західноукраїнській еміграції й визнавав іiі найбільш впливовою, та такою, яка підпорядкувала собі вихідців 3 Наддніпрянської України. Американський дипломат вважав великою проблемою західноукраїнської еміграції намагання перенести методи боротьби 3 польським урядом у міжвоєнний період на протидію режиму в СРСР. Неправильною була i концентрація уваги представників західноукраїнської еміграції тільки на західні регіони. Далі автор наголошував на розбіжностях у поглядах наддніпрянців i західних українців щодо проблем сутності радянського режиму та розбудови незалежної держави, але не бачив протиріч у соціальних питаннях. Об'єднавчими ідеями для всієї української еміграції Л. Гаррісон називав шовінізм, націоналізм та ідею великодержавності. Ці ідеї, відштовхували, на його думку, інші народи СРСР від українського руху, але з іншого боку - допомагали консолідували його та підтримували віру народу у власну перемогу.

Після перерви в активній діяльності український вільнокозацький рух відновився в нових організаційних формах та на нових засадах. Табори переміщених осіб залишилися в минулому, а їхні мешканці розпорошилися по нових країнах перебування. Центр українського життя перемістився до США i Канади. Після певного періоду пристосування до нових обставин та пошуків 
засобів до існування, представники “третьої хвилі” еміграції активізували власну діяльність.

На всіх етапах діяльності українського вільнокозацького руху важливе місце приділялося виданню офіційних органів УВК. Після перенесення центру діяльності Українського Вільного козацтва до Північної Америки постало питання про відновлення друку офіційного органу УВК. 31964 р. у Чикаго почав виходити неперіодичний орган “Українське Козацтво”. 31969 р. виходив журнал накладом уже у 500 примірників, але також не періодично. Після публікації першого номера редакція звернулася до своїх читачів із роз'ясненням власного ідейного напряму: “... Це напрям соборно-державницький з об’єктивним відношенням до історичної правди, бо “правдиве слово i камінь крушить”, та толерованням кожного самостійницько-державного світогляду. Ми підкреслюєм позитивні дії і не роздуваємо нападів, лайок і критики за хиби наших державних мужів 3 давнього i недавнього минулого. Цього напряму редакція тримається тому, що вірить, що і ті Побратими, які хотіли б бачити наш орган тільки скерованим у вузькому напрямі обслуговування лише політичної ідеології будь-якого одного середовища, з часом таки прийдуть до переконання в природній істині, що українська нація, а тому й українське козацтво, складаються 3 різно-світоглядових мас. А для кращих провідних представників тих середовищ має бути святим ідеалом любити і боротись за одну Україну і за один український народ!...” [13]. Подальші числа журналу викликали різні думки читачів, але більшість підтримувала відсутність політичного суперництва на сторінках i намагання журналу об'єднати представників різних ідеологічних напрямів [14]. 31972 р. "Українське Козацтво" стало щоквартальником накладом у 1000 примірників. Коштів на видання органу в Генеральній Управі УВК не було, але передплата та пожертви фінансували журнал. Пізніше він став друкуватися в Торонто. Співробітники та кореспонденти не одержували гонорари за публікацію в ньому [15]. Головним редактором органу УВК був до початку 1980-х pp. А. Кущинський, а потім його змінили Петро Коршун-Федоренко, Матвій Гута, Теодосій Волошин [16]. "Українське Козацтво" було науково-популярним виданням. У ньому публікувалися статті 3 воєннополітичної історії України, спогади, рецензії на наукові видання. Серед науковців на його шпальтах друкувалися Теодор Мацьків, Юрій Гаєцький, Роман Климкевич. Активні члени редколегії - Михайло Петруняк, Павло Баб'як, Володимир Засадний, Свген Курилюк, Ніна Котис, Аріадна Шум, часто виступали як автори статей та інших матеріалів журналу [17]. Регулярно щоквартальник видавався до 1982 р., були також спроби відновити його 1985 р.

Переходячи до висвітлення правового оформлення та організаційної структури УВК, необхідно зазначити, що організаційно-правові основи УВК було затверджено у 1946 - 1948 pp. Президентом УНР в екзилі А. Лівицьким та Українською національною радою. Відповідно до них збиралася Велика Козацька Рада, яка обирала Президію на час Ради і постійну Генеральну Раду, а також Військового Отамана, Генерального Секретаря, Генерального Контролера, Генерального Суддю та за пропозицію Військового Отамана Голову Генеральної Управи - заступника військового Отамана [18].

Зміни у становищі української еміграції та значне поширення вільнокозацького руху у світі змусили провести реформи в законодавчій базі та організаційній структурі УВК. Для цього було скликано Велику Козацьку Раду 31 квітня 1973 р. по 25 квітня 1974 р., яка проходила кореспонденційним способом. 
Було внесено зміни до Статуту, згідно з якими термін скликання Великої Козацької Ради було скорочено до трьох років. Термін дії органів управління та посадових осіб також скорочено до трьох років. Назву найвищої посади УВК було змінено 3 "Військового Отамана" на "Кошового Отамана УВК”. Первинні осередки організацій Вільного козацтва змінили назву зі “станиць” на “курені”. Їхні керівники одержали назву “курінні отамани”. Первинні організації раніше об”єднувалися в “область”, Велика Козацька Рада змінила їхню назву на “паланку”. Відповідно їх очолили “паланкові отамани”. Козацькі ранги, у тому числі і генеральські, поверталися до системи Української Держави 1918 р. "Генеральна Управа" одержала нову назву “Генеральна Булава". Кошовий Отаман одержав право призначати Генерального Писаря та редактора журналу "Українське Козацтво” [19]. Ще раніше у 1971 р. із метою розширення організації та набуття нею станового характеру було введено козацьке право. Відповідно до нього члени родини козака автоматично входили до козацтва. Позбавити членів УВК належності до козацького стану можливо було тільки за безчестя згідно з рішенням центрального органу організації [20].

Одним із головних напрямів діяльності УВК на еміграції було збереження військових традицій Запорозького козацтва та українських збройних формувань першої половини XX ст. Військова символіка та ії застосування займали важливе місце в заходах зі збереження традицій українського війська. Будь-яка військова частина бере початок із вручення військового прапора, а його втрата автоматично веде до розформування підрозділу. Тому не дивно, що виготовлення та посвята прапорів окремих станиць, а 31974 р. куренів, займали велике значення в діяльності вільнокозацьких організацій. До того ж, це було значним інформаційним приводом та важливою формою агітаційно-пропагандистської роботи. 21 листопада 1961 р. у Чикаго (США) було засновано фактично першу станицю у Північній Америці ім. Івана Омеляновича-Павленка. 8 листопада 1964 р., на другу річницю смерті І. Омеляновича-Павленка відбулася посвята прапору цієї станиці [21 - 23]. Пізніше більшість прапорів для станиць куренів УВК виготовляв Т. Бабюк з Рочестера (США). Прапори мали дві сторони жовто-блакитного та малинового кольорів. На малиновому тлі було зображено ікону Св. Покрови. Уперше такий прапор було посвячено 26 травня 1968 р. для станиці УВК № 5 ім. гетьмана Пилипа Орлика м. Валлей (Канада) [24].

Значну увагу осередки Вільного козацтва приділяли святкуванню різноманітних козацьких і патріотичних свят та пам'ятних дат. 14 жовтня кожного року всі станиці УВК на чотирьох континентах відзначали день Св. Покрови як свято українського козацтва та Збройних сил України новітньої доби. Почесний отаман П. Шандрук і його наступники видавали до кожного свята звернення до всіх станиць УВК [25]. 3 початку відродження організацій Вільного козацтва на початку 1960-х рр. станиці у Північній Америці, а потім і курені стали іменними. У назвах використовувалися як прізвища відомих діячів української історії різних часів - князя Володимира, княгині Ольги, С. Петлюри, П. Скоропадського, Т. Чупринки, так і пам'ятні події української історії - 22 січня, 1 листопада. Це пояснювалося регіональними, політичними та історичними уподобаннями членів УВК. Вихідці з Наддніпрянської України використовували історичні постаті Київської Русі, Козаччини, національно-визвольного руху 1917 - 1923 рр. Емігранти із західноукраїнських земель називали власні станиці на честь історичних постатей Галичини і Волині, діячів ОУН та УПА, або військових 
формувань, які воювали на боці нацистської Німеччини. У виховній та агітаційнопропагандистській роботі використовувалися заходи 3 увіковічнення пам'яті людей, на честь яких було названо станиці.

Одним із напрямів діяльності УВК було виховання української молоді на теренах перебування діаспори. Для цього створювалися окремі станиці, виховна робота проводилася і на тих, які було вже створено. 18 лютого 1973 р. у Чикаго було створено юнацьку станицю УВК № 26 ім. о. Агапія Гончаренка. Ініціатором була молодь, яку об'єднав священик Микола Литваківський [26]. Керівництво УВК приділяло багато уваги роботі з молоддю. Занепокоєння багатьох старих емігрантів викликало те, що українська молодь не може одержати вищу освіту, тому що платня за навчання постійно підвищується. На зустрічі з юнацькою станицею 30 грудня 1973 р. обласний отаман І. Сарвадій запропонував створити фінансовий фонд для навчання молоді. Він вніс для заснування фонду 1000 доларів. Передбачалося відшукати гроші серед старих бездітних емігрантів, які б могли залишити спадок на освіту молоді. Гроші повинні були збиратися на різноманітних заходах та козацьких святах [27].

У 1960 - 1980-х рр. український вільнокозацький рух активно продовжував антикомуністичну боротьбу в усьому світі. У червні 1970 р. Президенту США Річарду Ніксону було надіслано телеграму від керівництва УВК з підтримкою його політики у В’єтнамі. Керівники ВК П. Шандрук, В. Дяченко та В. Чопівський наголосили на продовженні боротьби проти комунізму. Зазначили, що українці пізнали підступність і злочинність тоталітарного режиму, а тому закликають твердо й безкомпромісно добиватися справедливого миру у В’єтнамі. На цю телеграму вони одержали відповідь від Р. Ніксона, у якій він висловив подяку за підтримку вояків у В'єтнамі та продовження безкомпромісної боротьби 3 комунізмом [28]. Антикомуністичні акції відбувалися і на теренах західних країн за участю емігрантів. Приводом до них були виступи радянських артистів у Ванкувері 22 - 23 серпня 1970 р. там виступав відомий танцювальний ансамбль Мойсєєва. Козаки і старшини 5-ї станиці УВК організували демонстрацію та пікетування. Було виготовлено летючки українською й англійською мовами 3 викладенням злочинів комуністичного режиму та закликами бойкотувати виступи радянських артистів. В акції брали участь не тільки члени ВК, але до них приєдналися багато українських емігрантів [29].

Зміни в СРСР у другій половині 1980-х рр. призвели до відродження козацького руху в Україні. Здобуття незалежності України ще більше активізувало козацький рух. Такі зміни в Україні вимагали від УВК співпраці 3 новими козацькими організаціями. Газета "Народна Армія" від 5 березня 1993 р. повідомила, що до організації "Українського козацтва" вирішили вступити осередки УВК у діаспорі і це питання буде розглянуто на позачерговій Великій Раді, яка пройде 15 - 16 травня 1993 р. у м. Луганськ [30]. Раніше, наприкінці 1992 р., Генеральна Булава УВК у Канаді прийняла рішення про об'єднання 3 новою козацькою організацією в Україні. Остаточне рішення про прийняття УВК колективним членом до "Українського козацтва" було прийнято в Києві 22 23 квітня 1993 р. і пізніше підтверджено на згаданій Великій Раді [31].

5 березня 2011 р., у м. Баффало (штат Нью-Йорк, США) в Українському культурному центрі “Дніпро" відбулася Велика Козацька Рада УкраїнськоАмериканського козацького Братства "Кіш Українського Вільного Козацтва у США”. Учасники: представники від організацій УВК з Клівленду, Чикаго, 
Рочестера, Нью-Джерсі, Канади та України; представники громадських патріотичних організацій. Велику Козацьку Раду очолив отаман УВК США Дармограй Юрій (м. Баффало), добре відомий у США громадський діяч i бізнесмен. Рада обговорила питання про стан і перспективи розвитку козацьких організацій УВК, офіційну реєстрацію Українсько-Американського козацького братства "Кіш Українського Вільного Козацтва у США”, створення станиць Коша УВК у США, призначення станичних отаманів, основні напрями діяльності УВК у США і в Україні [32]. Узагальнюючи все вищевикладене, зробимо наступні висновки. Після завершення Другої світової війни український вільнокозацький рух продовжував діяти головним чином, серед української діаспори за межами СРСР і соціалістичних країн. УВК було типовою парамілітарною громадською організацією. Членами організації були як колишні військові різних українських збройних формацій, так і емігранти “третьої хвилі”, представники інших хвиль української діаспори. Новим центром УВК на початку 1960-х рр. стала Північна Америка. Напрямами діяльності упродовж післявоєнних років були: збереження національної ідентичності та козацьких традицій; військово-патріотичне виховання представників української діаспори, агітаційно-пропагандистська діяльність із метою антикомуністичної боротьби, розробка воєнної доктрини та місця козацтва в майбутніх Збройних силах України, підготовка ідеології козацького руху та накопичення досвіду діяльності в умовах громадянського суспільства i демократичного ладу. У 1960 - 1980-ті рр. УВК зберігало єдність і не мало серйозних конфліктів усередині організації. Після здобуття незалежності України український вільнокозацький рух об'єднався 3 новими козацькими організаціями i продовжує свою діяльність до цього часу.

\section{Література}

1. Васильев В. По поводу одной фальшивки / В. Васильев, В. Соколов // Международная жизнь. - 1978. - № 8. - С. 124-128.

2. Павленко М. І. Біженці та переміщені особи в політиці імперіалістичних держав 1945 1949 pp. / М. Павленко. - К. : Наукова думка, 1979. - 123 с.

3. Коссар В. Шістдесят років в Канаді / В. Коссар // Календар-альманах “Нового Шляху” на 1951 рік. - Вінніпег : Друком і накладом “Нового Шляху”, 1950. - С. 127-153.

4. Мудрий В. Нова українська еміграція / В.Мудрий // Українці у вільному світі : ювілейна книга Українського Народного Союзу $(1894$ - 1954) / [зредагували Л. Мишуга, А. Драган]. - НьюЙорк : Видання УНС, 1954. - С. 115-136.

5. Gerus O. W. The Ukrainians in Canada / O. Gerus, J. Rea. - Ottawa, 1985. - 24 p.

6. Стрільчук Л. В. Українські політичні біженці та переміщені особи після Другої світової війни : дис. ... канд. іст. наук : 07.00.02 / Стрільчук Людмила Василівна. - Луцьк, 1999. - 174 с.

7. Стрільчук Л. В. Еміграція з України в роки Другої світової війни та після ії закінчення : політичний, національний та релігійний аспекти / Л. Стрільчук // Друга світова війна і доля народів України : матеріали 2-ї Всеукраїнської наукової конференції, м. Київ, 30-31 жовтня 2006 р. - К. : “Зовнішторгвидав України”, 2007. - С. 211-216.

8. Стрільчук Л. В. Українське політичне біженство наприкінці Другої світової війни та після ії завершення / Л.Стрільчук // Друга світова війна і доля народів України : тези доповідей 3-ї Всеукраїнської наукової конференції. - К. : “Зовнішторгвидав України”, 2008. - С. 56-57.

9. Рудик С. Я. Переселення українських біженців і переміщених осіб до США та Канади після Другої світової війни : причини, особливості, наслідки $(1945$ - 1953 рр.) : дис. ... канд. іст. наук : 07.00.02/ Рудик Сергій Ярославович. - К., 2003. - 177 с.

10. Недужко Ю. В. Державний центр Української Народної Республіки в екзилі (друга половина 40-х - 50-ті роки ХХ ст.) / Ю. Недужко. - НАН України, Ін-т історії України. - Луцьк : Волинська обласна друкарня, 2007. - 87 с.

11. Недужко Ю. В. Українська діаспора в процесі відновлення державної незалежності України (середина 40-х - початок 90-х років XX століття) : монографія / Ю. В. Недужко . - 
НАН України, Ін-т європ. дослідж. НАН України. - Луцьк : Волинська обласна друкарня, 2009. $618 \mathrm{c}$.

12. Недужко Ю. В. До причин державотворчої діяльності української діаспори в 40 - 90-х роках ХХ ст. / Ю. Недужко // Мандрівець. - 2009. - № 4. - С. 18-25.

C. 45 .

13. Пу-гу! Козаки з лугу! (Про наш журнал) // Українське Козацтво. - 1968/69. - № 2. -

14. Пу-гу! Козаки з лугу! (3 листів про наш журнал) // Українське Козацтво. - 1969. - № 3 4. - C. 55 . C. 40 .

15. В п’ятирічний ювілей “Українського козацтва” // Українське Козацтво. - 1974. - № 1. -

16. Ковальський М. До високоповажного побратима д-ра Матвія Гути сотника УВК / М. Ковальський // Українське Козацтво. - 1983. - № 2. - С. 76.

17. Мицик Ю.А. Українське козацтво / Ю. Мицик // Українське козацтво: мала енциклопедія / [кер. авт. колект. Ф. Г. Турченко]. - Вид. 2-е, доп. і перероб. - Київ : Генеза ; Запоріжжя : Прем'єр, 2006. - С. 493.

18. Центральний державний архів вищих органів влади та управління України (ЦДАВО України), ф. 5235, оп. 1, т. 1, спр. 1284, арк. 2-8.

19. Велика Козацька Рада // Українське Козацтво. - 1974. - № 3. - С. 4-7.

20. Шандрук П. Звернення до Генеральної Управи i всього Українського козацтва / П. Шандрук // Українське Козацтво. - 1971. - № 2. - С. 41 - 42.

21. Гайдук-Боберський В. Станиця УВК ім. генерал-бунчужного Івана ОмеляновичаПавленка в Чикаго, США / В.Гайдук-Боберський // Українське Козацтво. - 1968/1969. - № 2. C. $39-43$.

22. Витвицький С. Посвячення козацького прапора / С.Витвицький // Батьківщина. - 1964. 26 грудня.

23. Українське вільне козацтво : Посвячення прапору станиці ім. генерала Івана Омеляновича Павленка. - Чикаго, 1964. - 6 с.

C. $43-45$.

24. Ткачук В. Посвячення прапора / В.Ткачук // Українське Козацтво. - 1968/69. - № 2. -

25. Шандрук П. 3 нагоди свята Покрови в 1972 році / П.Шандрук // Українське Козацтво. 1973. - № 1. - C. 39.

26. Репа Г. Перш юнацька станиця УВК / Г.Репа // Українське Козацтво. - 1973. - № 2. C. $47-48$.

27. Репа Г. Обласний отаман відвідав юнацьку станицю / Г.Репа / Українське Козацтво. 1974. - № 2. - С. 46-47.

28. Телеграма Президентові США і відповідь на неї // Українське Козацтво. - 1971. - № 1. C. 41 .

29. Проти червоного дурману - проти московських танцюристів // Українське Козацтво. 1971. - № 1. - C. 45-46.

30. Козак скаже - як зав'яже // Народна Армія. - 1993. - 5 березня.

31. Зубков А. Канадські козаки - знову наші / А. Зубков // Народна Армія. - 1993. - 4 травня.

32. Велика Козацька Рада УВК в США [Електронний ресурс]. - Режим доступу: http://www.bratkozak.com.ua/news/velika_kozacka_rada_uvk_v_ssha/2011-03-05-118 - Дата звернення: 15. 07. 2015. - Назва з екрану.

\section{References}

1. VASIL'EV,V., SOKOLOV,V. (1978) Po povodu odnoj fal'shivki. Mezhdunarodnaja zhizn'. 8, p. 124-128.

2. PAVLENKO, M. (1979) Bizhentsi ta peremishcheni osoby v politytsi imperialistychnykh derzhav 1945 - $1949 \mathrm{rr}$. K. : Naukova dumka.

3. KOSSAR, V. (1950) Shistdesiat rokiv v Kanadi. Kalendar-almanakh "Novoho Shliakhu" na 1951 rik. Vinnipeh : Drukom i nakladom "Novoho Shliakhu", p. 127-153.

4. MUDRYI, V. (1954) Nova ukrainska emihratsiia. Ukraintsi u vilnomu sviti : yuvileina knyha Ukrainskoho Narodnoho Soiuzu (1894 - 1954). New York : Vydannia UNS, p. 115-136.

5. GERUS, O., REA, J. (1985) The Ukrainians in Canada. Ottawa.

6. STRILCHUK, L. (1999) Ukrainski politychni bizhentsi ta peremishcheni osoby pislia Druhoi svitovoi viiny. Unpublished Thesis (PhD), Volynskyi Derzhavniy Universytet imeni Lesi Ukrainki. 
7. STRILCHUK, L. (2007) Emihratsiia z Ukrainy v roky Druhoi svitovoi viiny ta pislia yii zakinchennia : politychnyi, natsionalnyi ta relihiinyi aspekty. Druha svitova viina i dolia narodiv Ukrainy : materialy 2-yi Vseukrainskoi naukovoi konferentsii, $m$. Kyiv, 30-31 zhovtnia 2006 r. K. : "Zovnishtorhvydav Ukrainy". P. 211-216.

8. STRILCHUK, L. (2008) Ukrainske politychne bizhenstvo naprykintsi Druhoi svitovoi viiny ta pislia yii zavershennia. Druha svitova viina i dolia narodiv Ukrainy : tezy dopovidei 3-yi Vseukrainskoi naukovoi konferentsii, K. : "Zovnishtorhvydav Ukrainy". P. 56-57.

9. RUDYK, S. (2003) Pereselennia ukrainskykh bizhentsiv i peremishchenykh osib do SShA ta Kanady pislia Druhoi svitovoi viiny : prychyny, osoblyvosti, naslidky (1945 - 1953 rr.) Unpublished Thesis (PhD), Chernivetskiy national'niy universitet imeni Yuriya Fed'kovycha.

10. NEDUZHKO, YU. (2007) Derzhavnyi tsentr Ukrainskoi Narodnoi Respubliky v ekzyli (druha polovyna 40-kh - 50-ti roky XX st.). NAN Ukrainy, In-t istorii Ukrainy. Lutsk : Volynska oblasna drukarnia.

11. NEDUZHKO, YU. (2009) Ukrainska diaspora $v$ protsesi vidnovlennia derzhavnoi nezalezhnosti Ukrainy (seredyna 40-kh-pochatok 90-kh rokiv XX stolittia) : monohrafiia. NAN Ukrainy, In-t yevrop. doslidzh. NAN Ukrainy. Lutsk : Volynska oblasna drukarnia.

12. NEDUZHKO, YU. (2009) Do prychyn derzhavotvorchoi diialnosti ukrainskoi diaspory v 40 90-kh rokakh XX st. Mandrivets. 4. P. 18-25.

13. Pu-hu! Kozaky z luhu! (Pro nash zhurnal) (1968/69). Ukrainske Kozatstvo. 2,. P. 45.

14. Pu-hu! Kozaky z luhu! (Z lystiv pro nash zhurnal) (1969). Ukrainske Kozatstvo. 3 - 4. P. 55.

15. V piatyrichnyi yuvilei "Ukrainskoho kozatstva" (1974). Ukrainske Kozatstvo. 1. P. 40.

16. KOVALSKYI, M. (1983) Do vysokopovazhnoho pobratyma d-ra Matviia Huty sotnyka UVK. Ukrainske Kozatstvo. 2. P. 76.

17. MYTSYK, YU. (2006) Ukrainske kozatstvo. Ukrainske kozatstvo : mala entsyklopediia. Vyd. 2-e, dop. i pererob. Kyiv : Heneza ; Zaporizhzhia : Premier.

18. Tsentralnyi derzhavnyi arkhiv vyshchykh orhaniv vlady ta upravlinnia Ukrainy, Kyiv (TSDAVO Ukrainy), f. 5235, op. 1, t. 1, spr. 1284, ark. 2-8.

19. Velyka Kozatska Rada (1974). Ukrainske Kozatstvo. 3. P. 4-7.

20. SHANDRUK, P. (1971) Zvernennia do Heneralnoi Upravy i vsoho Ukrainskoho kozatstva. Ukrainske Kozatstvo. 2. P. 41-42.

21. HAIDUK-BOBERSKYI, V. (1968/1969) Stanytsia UVK im. heneral-bunchuzhnoho Ivana Omelianovycha-Pavlenka v Chykaho, SSHA. Ukrainske Kozatstvo. 2. P. 39-43.

22. VYTVYTSKYI, S. (1964) Posviachennia kozatskoho prapora. Batkivshchyna. 26 hrudnia.

23. Ukrainske vilne kozatstvo : Posviachennia praporu stanytsi im. henerala Ivana Omelianovycha Pavlenka (1964). Chicago.

24. TKACHUK, V. (1968/69) Posviachennia prapora. Ukrainske Kozatstvo. 2. P. 43-45.

25. SHANDRUK, P. (1973) Z nahody sviata Pokrovy v 1972 rotsi. Ukrainske Kozatstvo. 1. P. 39.

26. REPA, H. (1973) Persha yunatska stanytsia UVK. Ukrainske Kozatstvo. 2. P. 47 - 48.

27. REPA, H. (1974) Oblasnyi otaman vidvidav yunatsku stanytsiu. Ukrainske Kozatstvo. 2. P. 46-

47.

28. Telehrama Prezydentovi SSHA i vidpovid na nei (1971). Ukrainske Kozatstvo. 1. P. 41.

29. Proty chervonoho durmanu - proty moskovskykh tantsiurystiv (1971). Ukrainske Kozatstvo. 1. P. $45-46$.

30. Kozak skazhe - yak zaviazhe (1993). Narodna Armiia, 5 bereznia.

31. ZUBKOV, A. (1993) Kanadski kozaky - znovu nashi. Narodna Armiia, 4 travnia.

32. Velyka Kozatska Rada UVK v SSHA (2015). [Online] Available from: http://www.bratkozak.com.ua/news/velika_kozacka_rada_uvk_v_ssha/2011-03-05-118 [Accessed: 15 th July 2015].

Надійшла до редколегії07.10.2017

Volodymyr Bondarenko, Dr. habil. (history), Associate Professor Zaporizhzhya National University, Zaporizhzhia

THE UKRAINIAN FREE COSSACKS MOVEMENT
IN THE USA AND CANADA IN $1960-1993$ 
Abstract. The article considers the basic problem of using the military-political experience of the Ukrainian Diaspora in the modern military construction of Ukraine. The Ukrainian Free Cossacks movement in 1960-1993 in the USA and Canada has been investigated. The peculiarities of the Ukrainian Free Cossacks movement in the 60's and 80's of the 20th century have been analyzed. The main directions of activity of organizations of the Free Cossacks in the USA and Canada have been determined. The reasons for the decline of movement in the mid-80's of the 20th century have been distinguished. The experience of the Ukrainian Free Cossacks in the United States and Canada is summarized for the further use in the activities of state bodies of Ukraine.

After the end of the Second World War, the Ukrainian Free Cossacks movement continued to operate mainly among the Ukrainian Diaspora outside the USSR and the socialist countries. The Ukrainian Free Cossacks was a typical paramilitary non government organization. North America was the new center of the Ukrainian Free Cossacks in the early 1960s. The following activities during the post-war years have been as follows: preserving the national identity and Cossack traditions; military-patriotic education of representatives of the Ukrainian Diaspora, propaganda campaign for the purpose of anti-communist struggle, developing the military doctrine and place of the Cossacks in the future Armed Forces of Ukraine, preparing the ideology of the Cossack movement and accumulating the experience in the conditions of civil society and democratic system.

Key words: Ukrainian Diaspora, military emigration, Ukrainian Free Cossacks movement, paramilitary public association, irregular armed formations, military construction, "third wave" of Ukrainian emigration.

\section{УДК 94:325.54 (71)«1976»}

Марія Бурцева, аспірантка, Державна установа «Інститут Всесвітньої історії НАН України»

\section{ЗАКОН ПРО ІММІГРАЦІЮ 1976 Р. ТА ПОЧАТОК НОВОЇ ЕРИ ДЕРЖАВНОЇ ПОЛТТИКИ КАНАДИ}

Анотація. У статті приділено увагу огляду переламних років для канадської історії загалом та імміграиійної політики Канади зокрема, якими була друга половина 1970-х рр. Знаковою подією иьього періоду стало прийняття Закону про імміграцію 1976 р., який визначив напрямок, пріоритети та цүілі канадської політики щуодо переселенців фактично до кіния XX cm. У тексті простежено пошук нового бачення імміграційної системи Канади, тому розглянуто часовий проміжок напередодні прийняття Закону 1976 р., а також перші роки після иъього, оскільки саме тоді було покладено початок новій ері канадської політики щзодо переселенців.

Авторкою проаналізовані фундаментальні законодавчі норми у питаннях політики щзодо переселениів, запроваджені протягом 1975-1978рp. Зокрема, окреслено нововведення і основні положення Закону про імміграцію 1976 р. Зрештою, дослідження містить інформацію про зміни у соціальній структурі переселенців до Канади, відстежені за даними статистики з імміграції у період до та після прийняття Закону $1976 \mathrm{p}$.

Ключові слова: Канада, імміграџійна політика, Закон про імміграцію 1976 р., імміграџійне законодавство, біжениі, лібералізація, дискримінація. 